\title{
Health care associated Clostridium difficile infections in University Hospital Trnava during last five years (2010 - 2014)
}

\author{
A Streharova ${ }^{1 *}$, M Garabasova $^{1}$, JS Brnova ${ }^{2,3}$ \\ From 3rd International Conference on Prevention and Infection Control (ICPIC 2015) \\ Geneva, Switzerland. 16-19 June 2015
}

\section{Introduction}

In Slovakia, mandatory surveillance of Clostridium difficile infection (CDI) have been established due to electronically national Epidemiological information systems (EPIS) long time ago, but compliance to surveillance are low.

\section{Objectives}

The aim of this hospital-based study was to assess real prevalence and outcome of CDI in University Hospital Trnava, Slovakia during years 2010-2014.

\section{Methods}

We analysed all patients with laboratory confirmed CDI (RIDA ${ }^{\circledR}$ QUICK Clostridium difficile Toxin A/B immunochromatographic rapid assay, R-Biopharm) in University Hospital Trnava (618-bed; approx. 25000 patients per year) from laboratory information system and medical records.

\section{Results}

During five years period were identified 317 CDI with declining trend in recent years for 10000 admission. Health care associated CDI (HA-CDI) accounted for $75,7 \%$ (240). The mean age of patients was $72,8 \pm 15$ years (range 15-96) and 60,3\% (191) were women. The most frequently antibiotics used before onset CDI were quinolones $(25,9 \%)$ for the treatment of respiration or urinary tract infection. Overall recurrence of CDI was observed within 3 months after the first episode in 6,9\% (22) of cases. Total hospital mortality rate was 13,9\% (44) and hospital mortality associated with CDI only $1,9 \%(6)$.

${ }^{1}$ Department of Public Health, Trnava University, Trnava, Slovakia

Full list of author information is available at the end of the article

\section{Conclusion}

These results show high prevalence HA-CDI in our hospital and emphasizing the importance of implementing better infection control practice in order to prevent further spread. To date no data about specific ribotype of Clostridium difficile and about prevalence in long-term care facility are available in Slovakia.

\section{Disclosure of interest}

None declared.

\section{Authors' details}

'Department of Public Health, Trnava University, Trnava, Slovakia. ${ }^{2}$ Department of Laboratory Medicine, School of Health Sciences and Social Work, Trnava University, Trnava, Slovakia. ${ }^{3}$ Laboratory of Molecular Microbiology, St. Elisabeth University, Bratislava, Slovakia.

Published: 16 June 2015

\section{doi:10.1186/2047-2994-4-S1-P24}

Cite this article as: Streharova et al:: Health care associated Clostridium difficile infections in University Hospital Trnava during last five years (2010 2014). Antimicrobial Resistance and Infection Control 2015 4(Suppl 1):P24.

Submit your next manuscript to BioMed Central and take full advantage of:

- Convenient online submission

- Thorough peer review

- No space constraints or color figure charges

- Immediate publication on acceptance

- Inclusion in PubMed, CAS, Scopus and Google Scholar

- Research which is freely available for redistribution 